\title{
Contributions Management of Parenting and Education Program to Strengthen the Service Three Early Childhood Education Center
}

\author{
Rudi Hariawan ${ }^{1}$, Nurul Ulfatin ${ }^{2}$, Muhammad Huda A. Y. ${ }^{2} \&$ Imron Arifin $^{2}$ \\ ${ }^{1}$ Department of Educational Administration, IKIP of Mataram, West Nusa Tenggara Province, Indonesia \\ ${ }^{2}$ Department of Educational Administration, State University of Malang, East Java, Indonesia \\ Correspondence: Rudi Hariawan, Department of Educational Administration, Faculty of Education, IKIP of \\ Mataram, Jalan Pemuda No. 59A Mataram, West Nusa Tenggara Province 83125, Indonesia. Tel: 370-632-082. \\ E-mail: rudiap@ikipmataram.ac.id
}

Received: September 30, 2018

doi:10.5539/ies.v12n2p100

\author{
Accepted: November 2, 2018 \\ Online Published: January 30, 2019 \\ URL: https://doi.org/10.5539/ies.v12n2p100
}

\begin{abstract}
Early age is a "golden moment" which will not be repeated in the period of child development. A rare opportunity must be utilized to provide the best education and care in three centers, namely; school, family and community environment. The purpose of this research is to; 1) Describe the contribution of parenting education management; and 2) Describe the practice of parenting education in three education centers. This research method uses a qualitative approach with a multi-case study design. These informants were teachers, principals, and parents of students from the two Early Childhood Education institutions in the West Nusa Tenggara Province, Indonesia. Data collection is done by in-depth interviews with informants, participatory observation, and documentation review. The results revealed that; 1 ) a positive contribution to the management of education and parenting in three education centers with the following stages; first, Plan-collaboration in designing the parenting education program; second, Do-collaboration in the parenting education program at school and inactivating it in the family and community environment, and third, Check-control and evaluate program achievements, then make a follow-up plan for the program; 2) Implementation, in; first-family environment strengthens the relationship between mother and child, the growing sense of self-confidence of parents in educating and caring for their children; second kindergartens environment by holding parenting education activities, holding days of child development consultations, building relationships, support and trust in schools; and third-community environment is the application of local wisdom values by community members.
\end{abstract}

Keywords: parenting education, management, three centers of education, early childhood education

\section{Introduction}

\subsection{Background}

Experts divide the period of growth and development of children up to the age of 12 years into 6 periods (Hurlock, 1980; Kardjono, 2008). Whereas, the development of preschool children is called by experts as the golden age period. Children can achieve development of up to $80 \%$ before a child is 8 years old or faster than age after. The specific Kardjono (2008) describes the intended period is a period of children aged between 2 and 6 years. Positive development during the period of early childhood proved to correlate positively with achievement of learning in school, productivity in learning, toughness, and responsibilities as members of society (Pandia, Widyawati, Y.S., Irwan, \& Irwanto, 2012)

Child development is influenced by various factors that make up the including the influence of family environment and community. Family environment such as parenting practices, the level of welfare, and education. While the influence of the environment community such as the existence of the education service and early childhood development. The influence of the environment significantly affects the social actions of the child in adolescence (Caughy et al., 2012).

Developmental ecological theory which explains that children are influenced by complex interaction systems with various levels of the surrounding environment that interact and relate between children's environment inside and outside the home from a child's life in a very long period of time (Bronfenbrenner, 2005; Izzaty, 2013). In Indonesia, the interaction between the environment is known as the "three centers of education" namely education 
that takes place in the family, school and community. Hariawan and Faqih (2014) revealed that the term three centers of education was introduced by an Indonesian education figure since the 1930s, named Ki Hajar Dewantara. According to Ki Hajar Dewantara this environment can only be distinguished, but cannot be separated or run independently, because education is an integrated activity and does not take place separately.

With education and positive parenting can develop children's independence, when communicating or interacting with children always use the right words and actions, provide support, be consistent, calm, listen, relax, and respond (Sunarty \& Dirawan, 2015). Positive parenting, understood as a series of actions and practices carried out by parents to foster the psychological development of their children, is realized through a series of competencies to produce a family environment that strengthens protective factors, minimizes risk and has a positive impact on the quality of child development (Arranz et al., 2016).

It can be interpreted that every parent must have parenting skills, to avoid the practice of education and the practice of wrong parenting. People on the Lombok island, West Nusa Tenggara Province, Indonesia, where this research was carried out, there are still parents of students who think that the father and mother of students are only responsible for fulfilling the biological needs and education costs of their children, while for the matter of educating children fully becomes the responsibility of the teachers in the school. This kind of assumption can break the education ecosystem that affects children's development, because education is an integrated one and is a shared responsibility. There is an urgent need for schools and families to collaborate which aims to encourage joint actions and responsibilities between systems that take place in the family environment and at school (Arranz et al., 2016).

School responsibilities in addition to organizing education and teaching programs; also manage harmonious relationships with family members and communities in creating a healthy educational environment for child development. This pre-school age can be used as a valuable momentum that will not be repeated in the period of child development. This is the opportunity for children to get the best education and parenting.

In addition to consideration of the need for parenting and education for pre-school age children, there are other things that are taken into consideration the authors conducted in-depth research on Early Childhood Education (ECE) institutions in Lombok island, West Nusa Tenggara province, namely: Kindergarten of Idhata and ECE of Al-Anshor.

Kindergarten of Idhata is a private school, owned by the Dharma Wanita Foundation of the Ministry of Education and Culture of the Province of West Nusa Tenggara, Indonesia, located in the Gomong village, Mataram city. Many educational institutions were established from the level of primary education to higher education available in this city. Based on information obtained from the head of Kindergarten of Idhata that his students mostly came from economically disadvantaged families living around the village of Gomong, Mataram City, and the rest were students from families who happened to be their parents working close to then Kindergarten of Idhata. The parents of students in Kindergarten of Idhata have many undergraduates and are dominated by parents of junior and senior high school graduates with professions as small traders, construction laborers, scavengers, and parking attendants and others working as employees in private and government offices.

Conditions that are not much different from ECE of Al-Anshor, this educational institution is managed by the private sector (owned by the foundation). The ECE of Al-Anshor which is about 15 kilometers from Lombok International Airport, West Nusa Tenggara Province. It is located far from the city center and the average population is a farmer and construction worker with an average junior and senior high school education level. The number of early childhood education services has caused the ECE of Al-Anshor institution to be the closest choice for the surrounding community to educate their children.

The condition of these two educational institutions is a challenge for organizers of early childhood education to be able to involve parents and the community in creating an educational environment that has a positive impact on children's development. By paying attention to educational background, economic level, and family welfare, it is possible for parents to give wrong education and apply wrong parenting to their children. Education and care carried out by trial and error without proper training and guidance will only get unpredictable results (Hosseini et al., 2013). Management's contribution in managing the parenting education program is expected to encourage the formation of school relations with families and communities as three effective centers of education.

Based on several descriptions of the conditions of the two education units, this is what researchers consider in revealing the contribution of parenting education management in strengthening services in three centers of early childhood education on the Lombok Island, West Nusa Tenggara province, Indonesia 


\subsection{The Research Objective}

The main objective in the study was to describe the contribution of parenting education management and the implementation of three education centers.

\subsection{Benefits of Research}

1) Theoretical benefits, theoretically from the results of this study is to enrich the scientific repertoire in the field of student management, especially at the level of early childhood education

2) A practical benefit, practically from the results of this study is to provide information and knowledge to teachers, parents, community elements about the management of three centers of early childhood education.

\section{Method}

This study uses a qualitative approach with a multi-case study design, this design was chosen to reveal naturally about events or phenomena that occurred in Kindergarten of Idhata and ECE of Al-Anshor at Lombok, West Nusa Tenggara Province, Indonesia.

\subsection{Subjects}

The subjects of this study were teachers, principals, parents, chairmen of school committees, religious leaders, and community leaders, who are referred to as key informants can be seen in table 1, totaling 32 informants.

\subsection{Sample}

With respect to the draft study multi case selected by the researcher, then the researchers do the determination of subjects of research with sampling purposive snowball technique, This technique is used to spool the data widely through selecting appropriate informants have information related research objectives include the teachers and the principals and the parents of the students of both ECE/Kindergarten. For parents are those who have preschool age children a year and is active in both the student unit of education places this research implemented.

Table 1. Information data of research subjects

\begin{tabular}{ccc}
\hline & \multicolumn{2}{c}{ Location Research } \\
\cline { 2 - 3 } Subject & Kindergarten of Idhata (Case I) & $\begin{array}{c}\text { ECE of Al-Anshor } \\
\text { (Case II) }\end{array}$ \\
\hline Principle & 1 & 1 \\
Teacher & 2 & 2 \\
Parents or guardians of pupils & 10 & 10 \\
School Committee Chairman & 1 & 1 \\
Religious figure & 1 & 1 \\
Public figure & 1 & 1 \\
Total & 16 & 16 \\
\hline
\end{tabular}

Note. The informants selected at the researcher's discretion and advice from the principal

\subsection{Instrument}

In this study, researchers act as key instruments because the researcher is collecting data in field. Researchers present research without being represented in what to play an active role in doing data collection overall to the exclusion of the element of subjectivity, then researchers analyzing and compiling reports of research

\subsection{Procedures}

Data collection procedure in this study was done through three ways, namely (1) in-depth interviews; (2) the participant observation, and study the documentation. This type of observation is observation of passive participation, where researchers did not participate directly in the activities undertaken subject of research, but researchers only as observers.

\subsection{Design}

The analysis of the data used in this study there are two, namely: (1) individual case data analysis; and (2) data analysis of cross cases.

Individual case data analysis was done through the collection of data, data presentation, data reduction, and make conclusions and verification. 


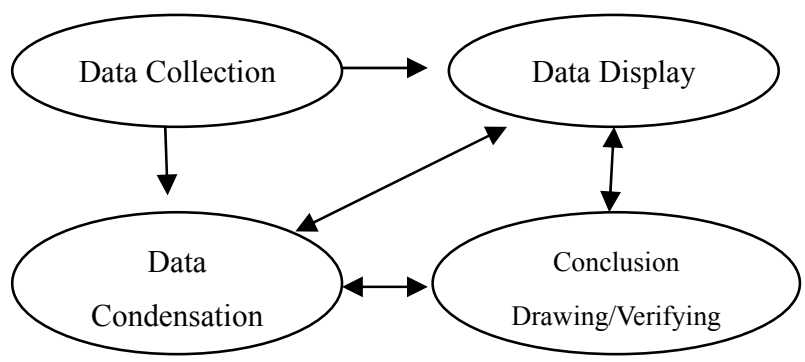

Figure 1. Interactive model of data analysis of Miles, Huberman, and Saldana (2014)

While the cross-case analysis in this research is an activity comparing and combining the results of the findings in case 1 (Kindergarten of Idhata) and case 2 (ECE of Al-Anshor).

The following is a cross-case analysis conducted by researchers: (1) researchers performing data collection on the case so I produce research findings case I, (2) the researcher doing data collection on the case II resulting in research findings case II; (3) a cross-case analysis researchers, i.e. by combining and comparing between research findings case I and case II research findings. At this stage of the analysis of this case, the researchers also match data with facts, if there is a mismatch in the correction data will be returned in a way back in the previous phase, (4) a cross-case analysis results of later researchers found a cross-case findings, (5) the results of the analysis of these cases later became substantive theory; and (6) making the conclusion.

Checking the validity of the data in this study was conducted over 4 test criteria of validity of data namely credibility, transferbility, dependability, and confirmability. A test of credibility in this research was conducted do triangulation data or sources and triangulation methods. This research was conducted with five stages, namely: (1) introduction research context; (2) the establishment of a research context; (3) implementation; (4) examination results and checking the validity of data; (5) the final stage as the report writing

\section{Results}

These findings are in the form of case study findings 1, case study findings 2 , and findings of cross-case studies. In summary, the results of this study can be illustrated in the findings of cross-case studies. The findings of the cross-case study are the results of the comparison of the two objectives in case study findings1, and case study findings 2. Overall, the cross-case findings in this study are presented in the form of context diagrams as shown in Figure 2.

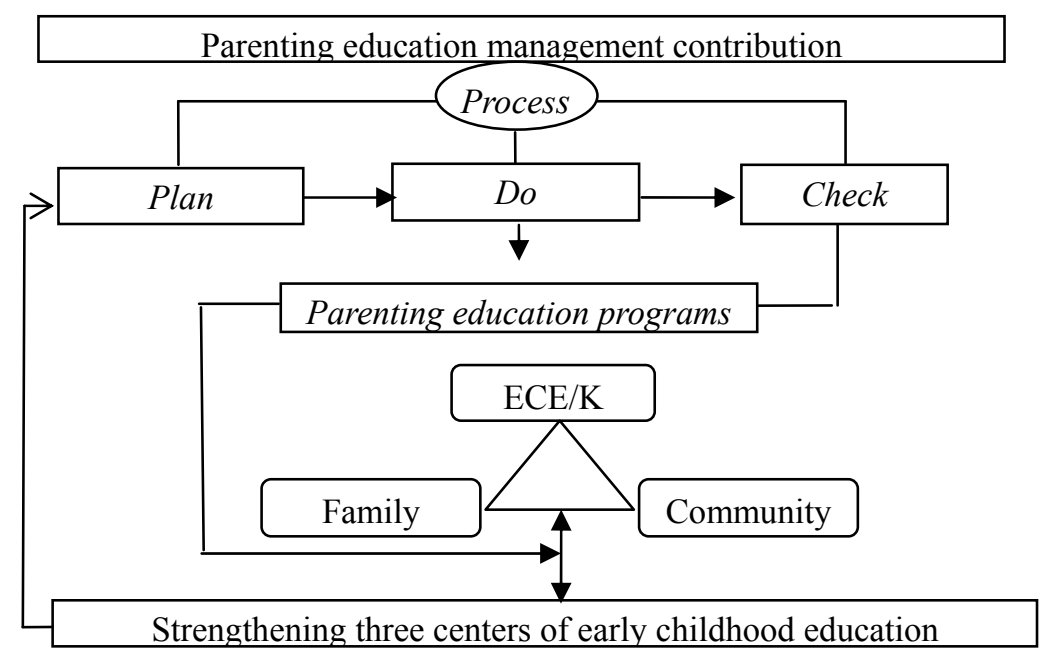

Figure 2. Cross-case findings

Based on the cross-case finding diagram as shown in Figure 2, the following research findings can be obtained: 1) the contribution of parenting education management aims to achieve collaboration in education and parenting in three centers of education with the following stages: (a) Plan, namely early childhood education institutions 
together with parents and communities to design parenting education programs; (b) $d o$, that is parenting education programs implemented in schools and apply it on the family environment and community; (c) Check: conduct control and evaluate program achievements and practices, then make a follow-up plan for the program.2) The implementation of three education centers aims to create an educational environment that supports children's development as a whole in the family, school and community environment, in a way; (a) The family environment, the application of parenting in the form of strengthening relationships and fostering parents' confidence in providing education and parenting to their children, as well as providing guidance and providing learning facilities to their children; (b) School environment, the school organizes parenting and education activities for parents, in the form of providing a day of consultation for child growth and development, building partnerships and support with parents and the community as stakeholders for schools; (c) Community environment, the application of parenting is adjusted to the application of the values of local wisdom adopted by the community, namely religious, cultural and moral values.

\section{Discussion}

\subsection{Parenting Education Management Contribution}

The contribution of parenting education management aims to achieve collaboration in education and parenting in three educational environments, namely: family, school and community.

The contribution of parenting education management can be said to have been carried out according to the management functions and processes. Early childhood education institutions make work programs carried out together with parents of students, and involve community and religious leaders who are members of the school committee.

Common constraints that are still found in units of early childhood education are the perception of some people that the task of educating is the responsibility of educators in schools, while parents fulfill their biological needs and education costs. To overcome this obstacle the school should establish harmonious communication with the family and the community by providing an understanding of the correct education and parenting. One theory that is also applied in a program to improve parenting skills is the Triple-P (Positive Parenting Program), this program applies positive management skills between parents and children in parenting (Sanders, Cann, \& Markie-Dadds, 2003)

All parenting education programs are directed to achieve educational collaboration and parenting carried out by early childhood education institutions with programmed families and communities. Sufficient findings simplified management processes in accordance with the complex needs of the work. The simplification of the management process in question is the stages of the planning, implementation and evaluation process into Plan-Do-Check.

\subsubsection{Plan}

The planning of the parenting education program involves elements of teachers, parents, and communities who join the school committee. The guidelines used in the preparation of the parenting education program are technical guidelines for the partnership of schools, families and communities that are published by the Indonesian Ministry of Education and Culture (Iskandar \& Sukiman, 2016).The planned programs are programs tailored to the needs and conditions of each unit of early childhood education institutions.

\subsubsection{Do}

Do is implementing the parenting education program in educational institutions and implementing it in the family and community environment.

The process of implementing the parenting education program should be the easiest stage because it only carries out activities as planned, but based on research findings that the implementation process is said to be a fairly difficult stage. The difficulty is the low level of parental attendance in participating in the parenting education program held in educational institutions. As a result the practice of parenting parents against their children is not optimal. Though some parenting education programs are only carried out once a year.

The impact of social change from local community values can be a positive parenting practice for children's social development. The local wisdom of the people of Lombok is known as a religious community and is rich in local cultural values, so that in 2015 and 2016 Lombok Island was awarded the World Halal Tourism Award (WHTA). Practice the value of local wisdom is reflected in the habit of gathering in to help each other, polite and welcoming, intelligent respect and respect for others.

\subsubsection{Check}

Check interpreted in this study as evaluation. The results of this study found that the parenting education program 
evaluation in institutional and personal assessment. Institutional Assessment by submitting a written notification to the school committee for further is taken into consideration in preparing the program for the period of the next year. Personal evaluation conducted by assessing changes in attitude and behavior of parents towards their children or the children to her parents, and children to teachers and friends in the interaction at school.

\subsection{Three Centers of Education}

The implementation of three education centers aims to create an educational environment that supports children's development as a whole in the family, school and community environment.

According to the Regio Amelia, there are three places that have great influence and become a teacher in the development of the capacity in early childhood that is parents, teachers at the school and the environment (Arifin, 2009). Ki Hajar Dewantara called it the "three centers of education" that took place in the family, school and community. If a child fails in an effort to achieve the task of development, it can lead to two serious possibilities, namely: (1) the child is assessed by his peers as a child whose development is late, and this assessment makes the child concerned has a negative assessment of himself, and in the end makes the child have a negative self-image; and (2) the foundation for the next stage of development becomes less powerful so it is difficult to catch up with the development of peers (Hurlock, 1980)

It can be concluded that the implementation of the three centers of education aims to build relationships and collaboration in minimizing the impact of educational practices and parenting wrong to their children.

\subsubsection{Family Environment}

Application of parenting in the home is to provide support, guidance and control during the learning at home, strengthen relationships with their parents.

The effectiveness of implementing parenting education for parents to their children at home is to help parents overcome various problems and obtain the latest knowledge and information about education and parenting.Based on data obtained in both childhood education unit dinitemukan that about $70 \%$ of the students are parents with low educational levelsor not undergraduate

Whereas the level of education have the most influence in the practice of education of children at home so it is the most important component in the school readiness of children (Priyono, 2017). This parenting activity is not just caring for children but is responsible for educating them. Through parenting from his parents, the child will go through step by step development in his life (Nugraheni \& Fakhruddin, 2014)

The problem of low levels of education will be overcome if early childhood education institutions organize parenting and education programs in their institutions. The level of school readiness in children whose parents are highly educated and do not participate in parenting programs in early childhood education units, will have a level of school readiness that is almost the same as that of children whose parents have low education, but follows a parenting program in early childhood education units.

The level of education is only one of the positive carrying capacity that helps children achieve maximum growth and development. Every parent still has many opportunities as well as being the main educator at home by following the parenting education program in early childhood education institutions. Parenting education activities can be used as a means to add and share information about the right insight and parenting.Educators and parents can share information and knowledge about how to educate and care for children. Parenting in a family environment other than (father-mother), other family members must also be able to act as educators

According to Ki Hajar Dewantara "The family is the educational environment is first and foremost" (Hariawan \& Faqih, 2014). Thus, the role of the family in terms of education for children cannot be replaced even though children have been educated in formal and non-formal educational institutions. For this reason, families must have the ability to carry out the process of improving nutrition and health, care, parenting, education and protection. The task of educating children in a family environment is preferably handed over to mother. Because mother is the main educator in the family (mother is the first educational institution for children). The family is the first environment that children receive, as well as the foundation for children's personal development.

In families where fathers had attained a higherlevel of education, children have a bigger chance of obtaining better learning experience at home. This may be influenced by the patrilineal tendencies in Indonesian culture (Pandia et al., 2012).

\subsubsection{School Environment}

The school acts as the organizer of parenting education activities, consulting child growth and development, building relationships, support and trust of parents and the community as stakeholders for the school. 
Entering preschool age, the role has been influenced by other parties, namely schools. School is the second environment for children, which has a very large role for the formation of the child's personality. The best effort is close and communicative cooperation between the family and the school. Instill a different perspective on children that parents are the first and foremost teacher for children, Instilling a different perspective to the child that the parent is the first and primary teacher for children, while teachers at the school is the second parent to child. The teacher has a background in knowledge about the development of children which is a source of knowledge for parents, as well as the teachers also need parents to obtain valid information about the character and potential of children that need to be developed in school (Olsen\& Fuller, 2003).

The lack of correlation between children's education programs and training for parents of students can hinder participation in learning their children (Pandia et al., 2012). The parents' participation in improving the quality of education of elementary schools is manifested in the aspects of learning, students' affair, facilities and infrastructure, public relations, educational finance, and school personnel (Sumarsono, Imron, Wiyono, \& Arifin, 2016).

Managers of educational institutions can build organized relationships by maximizing the function of school committees or associations to accommodate parenting activities in their institutions. Thus, the school does not only function as a vehicle for learning that is safe and enjoyable for children in school, but as a means of learning and exchanging information between teachers and parents of students.

\subsubsection{Community Environment}

The practice of parenting education by community members is carried out through civilizing the value of local wisdom. This practice can be observed in their daily interactions individually and in groups, caring for others and assuming that people in their community are part of their family. So that whoever they are, they will remain under the supervision of the community in their environment. Children are afraid to skip school; children do not dare to commit immoral acts. This is what might be meant as an unlimited educational institution (Hosseini et al., 2013).

According to Priyono (2017) intervention from respected religious and community leaders is also needed in this regard. The cultural influence of the surrounding community is also considered relevant as an influential factor in the formation of child behavior (Kardjono, 2008). For example, physical aspects of society such as the availability of playgrounds and safe neighboring lives, community resources, such as the availability and quality of preschool environments, the existence of parental work and educational and health institutions have all been hypothesized to influence the quality of children's environments and ultimately improve quality child development.

Marian Diamond is a professor of neuro anatomy at the University of California, and the author of Heredity, saying that the brain is greatly affected by its environment, not only by heredity. Every child's experience, whether at home, at school, or in the community, will provide certain stimuli to him.

\section{Conclusions and Recommendations}

\subsection{Conclusion}

Based on the discussion of the results of this study, it can be concluded, as follows:

1) Management contributes positively in integrating education and parenting programs for early childhood in three education centers through a management process, beginning with plan-collaboration in designing parenting education programs; second, do-collaboration in parenting education programs in schools and practicing them in the family and community environment; and third, check-control and evaluate the program's achievements and practices, then make a plan for the follow-up program.

2) Implementation of parenting education that takes place in three environments: first, family environment, by strengthening the relationship between mother and child, the growing sense of confidence in parents in educating and caring for their children; second, the school environment, by organizing parenting education activities, holding a children's development consultation day, building relationships, support and trust in the school; and third, community environment, by applying local wisdom values by community members.

\subsection{Recommendations}

1) To organizers of early childhood education, that the management of parenting and education programs is very important to be carried out to build strength and collaboration in education and parenting between educational institutions and family members and community members.

2) To other researchers, a more in-depth study needs to be carried out about the impact of the local wisdom of the community on children's development, because each region or country has different local wisdom. 


\section{References}

Arifin, I. (2009). The Brigging Programme: Berbasis Pendekatan Reggio Emilia. Jakarta: Aditya Media

Arranz, E. B., Olabarrieta, F., Manzano, A., Martín, J. L., Cruz, N., \& Etxaniz, A. (2016). Assessment of positive parenting programmes in the Autonomous Region of the Basque Country (Spain). Psychosocial Intervention, 25(2), 127-134. https://doi.org/10.1016/j.psi.2016.03.003

Bronfenbrenner, U. (2005). Making Human Beings Human: Bioecological Perspectives on Human Development. London: Sage Publication

Caughy, M. O. B., Franzini, L., Windle, M., Dittus, P., Cuccaro, P., Elliott, M. N., \& Schuster, M. A. (2012). Social Competence in Late Elementary School: Relationships to Parenting and Neighborhood Context. Journal of Youth and Adolescence, 41(12), 1613-1627. https://doi.org/10.1007/s10964-012-9779-2

Iskandar, H., \& Sukiman (2016). Kemitraan Satuan Pendidikan Anak Usia Dini (PAUD) dengan Keluarga dan Masyarakat. Jakarta. Retrieved from http://118.98.227.114/glnsite/wp-content/uploads/2017/09/Juknis_PAUD.pdf

Hariawan, R. (2011). Manajemen Program Parenting pada PAUD Unggulan Nasional (Unpublished Theses). Universitas Negeri Malang.

Hariawan, R., \& Faqih, M. (2014). Implementasi Parenting Education in School pada Jenjang Pendidikan Dasar di Lombok Tengah. Jurnal Kependidikan, 13(4), 415-420. Retrieved from http://lppm.ikipmataram.ac.id/wp-content/uploads/2015/03/Rudi-Hariawan-Muhammad-Faqih.-Implementa si-Parenting-Education-in-School.-Jurnal-Kependidikan-Edisi-Desember-2014-Vol.-13-No.-4.pdf

Hosseini, F., Yassini A., S. M., Shadcaam, M. N., Kholasezadeh, G., Khoshabi, K., \& Shahmansouri, N. (2013). The Effect of the Parenting Skills in the Attitude of Preschool Students' Mothers. Procedia-Social and Behavioral Sciences, 84, 1053-1058. https://doi.org/10.1016/j.sbspro.2013.06.698

Hurlock, E. B. (1980/1991). Psikologi Perkembangan: Suatu pendekatan sepanjang rentang Kehidupan. Fifth edition (Istiwidayanti. Soedjarwo \& R. M. Sijabat, Trans.). Jakarta: Erlangga

Izzaty, R. E. (2013). Peran Aktivitas Pengasuhan pada Pembentukan Perilaku Anak sejak Usia Dini ; Kajian Psikologis berdasarkan Teori Sistem Ekologis. Retrieved from http://staff.uny.ac.id/sites/default/files/lain-lain/dr-rita-eka-izzaty-spsi-msi/MAKALAH PAUD.pdf

Miles, M. B., Huberman, M. A., \& Saldana, J. (2014). Qualitatuve Data Analysis (3rd ed.). California: SAGE Publication, Inc.

Nugraheni, S., \& Fakhruddin. (2014). Persepsi Dan Partisipasi Orang Tua Terhadap Lembaga Paud Sebagai Tempat Pendidikan Untuk Anak Usia Dini (Studi Pada Orang Tua Di Desa Tragung Kecamatan Kandeman Kabupaten Batang). Journal of Nonformal Education, 3(2), 49-57. Retrieved from http://journal.unnes.ac.id/sju/index.php/jnfc/article/view/3739

Olsen, G., \& Fuller, M. L. (2003). Home-School Relations. Boston: Allyn and Bacon

Pandia, W. S. S., Widyawati, Y., Irwan, A. Y. S., \& Irwanto. (2012). School Readiness and The Influencing Factors. SMERU Research Institute (pp. 14-23). Retrieved from http://www.smeru.or.id/sites/default/files/publication/news33.pdf

Priyono. (2017). Early Childhood Education in Banten: Cultural capital and school readiness. SMERU $\begin{array}{lllll}\text { Research Institute } & \text { (pp. 31-37). from }\end{array}$ http://www.smeru.or.id/sites/default/files/publication/news33.pdf

Reyes, D. (2004). You Can Stay Young and Healthy. Wordlink Marketing Corporation.

Sanders, M. R., Cann, W., \& Markie-Dadds, C. (2003). The triple P-positive parenting programme: A universal population-level approach to the prevention of child abuse. Child Abuse Review, 12(3), 155-171. https://doi.org/10.1002/car.798

Sumarsono, R. B., Imron, A., Wiyono, B. B., \& Arifin, I. (2016). Parents' Participation in Improving the Quality of Elementary School in the City of Malang, East Java, Indonesia. International Education Studies, 9(10), 256. https://doi.org/10.5539/ies.v9n10p256

Sunarty, K., \& Dirawan, G. D. (2015). Development Parenting Model to Increase the Independence of Children. International Education Studies, 8(10), 107-114. https://doi.org/10.5539/ies.v8n10p107 


\section{Copyrights}

Copyright for this article is retained by the author(s), with first publication rights granted to the journal.

This is an open-access article distributed under the terms and conditions of the Creative Commons Attribution license (http://creativecommons.org/licenses/by/4.0/). 